\title{
Proceeding
}

Supplementary Issue: Autumn Conferences of Sports Science. Costa Blanca Sports Science Events, 18-19 December 2020. Alicante, Spain.

\section{The effect of motor development in adolescence on cognition: A cumulative literature review}

\author{
GIUSI ANTONIA TOTO , PIERPAOLO LIMONE \\ Department of Humanities, Literature, Cultural Heritage and Education Sciences, University of Foggia, Italy
}

\begin{abstract}
The equal motor activity of the other sense organs is a prerequisite for the development of cognitive processes. The methodology used is a cumulative literature review structured on 10 systematic phases and is replicable. Showing considerable potential for cumulative research, the theory of motor development in adolescence appears to be a promising topic for a literature review and especially for the development of developmental psychology. The articles selected, starting from Gibson's theory of 1979, use the concept of affordance as a principle of mediation between the environment and the development of the body. The modern view of motor development emphasizes the connection between genetic factors and environmental factors and that motor behaviour is the expression of this intrinsic interaction. The results produced suggest a functional relationship between action and language and, more generally, parallel development between cognitive, social-affective, and motor development. Conclusion: This evidence allows us to structure training courses in adolescence with effects on multiple cognitive domains. In addition to muscle development, the competence and development of movement is also explained through the balance of different subsystems. Keywords: Motor development; Cumulative literature review; Cognition; Adolescence.
\end{abstract}

\section{Cite this article as:}

Toto, G.A., \& Limone, P. (2021). The effect of motor development in adolescence on cognition: A cumulative literature review. Journal of Human Sport and Exercise, 16(2proc), S663-S670. doi:https://doi.org/10.14198/jhse.2021.16.Proc2.51

Corresponding author. Department of Humanities, Literature, Cultural Heritage and Education Sciences, University of Foggia, Italy. https://orcid.org/0000-0001-5538-5858

E-mail: giusy.toto@unifg.it

Abstract submitted to: Autumn Conferences of Sports Science. Costa Blanca Sports Science Events, 18-19 December 2020. Alicante, Spain.

JOURNAL OF HUMAN SPORT \& EXERCISE ISSN 1988-5202

(C) Faculty of Education. University of Alicante

doi:10.14198/jhse.2021.16.Proc2.51 


\section{INTRODUCTION}

In the last decade (2010-2020) the two main themes in contemporary developmental psychology research in general and in relation to motor development in particular have been the components and functions of movement in children. With this second term, in reality, we also refer to the cognitive, perceptual and emotional correlates established during the stages of development (French, et al., 2020). Scientific evidence has shown that there is a two-way relationship between motor development and the development of cognitive components. Therefore, the focus of research has increasingly been oriented towards a multidisciplinary perspective (Limone \& Toto, 2018). Unlike perceptual and cognitive processes in the strict sense, motor development is directly observable and measurable, opening a new perspective within the study of the human mind. Furthermore, in the first years of a child's life, his relationship with the environment produces direct effects on perception, learning, decision making and social development. It is therefore believed that a culturally rich environment favours motor development and the consequent cognitive dynamics. The components of the movement are divided into motor patterns and postural patterns (). The former are dynamic and develop on the dimensions of length, width and height of space and in the dimension of time (running, for example). The postural patterns instead, for instance, can be both static and dynamic, and develop only in the three dimensions of space (e.g., flexing or bending). Therefore, motor skills are those physical characteristics that allow the individual to learn as a function of motor actions (and if they are broken down into perceptual, conditional, coordinative and joint mobility skills). This research has once again demonstrated the scarcity of studies in relation to certain age groups, despite the relationship between cognitive and motor development and the analytical tools used to examine it at a fairly refined methodological level (Rollo et al., 2017). In particular, the motor system is integrated with the other systems involved in the development of the person. This synergy makes it possible to carry out behaviours appropriate to the context, or to achieve set goals. Through neuronal correlates, motor development allows brain maturation (with all the elements involved).

The Clark-Metcalfe study (2002) broke down motor development into six fundamental stages - reflexes, preadapted movements, basic patterns, context-specific movements, skilful movements and compensation comparing it to the metaphor of mountain climbing. The purpose of the contribution is to show the evolution and focus of studies with respect to contemporary and shared taxonomies of the analysis of motor and cognitive development. Motor development tends to be broken down into neo-natal development ( $0-2$ years), childhood (3-5 years), school age (6-13 years), adolescent (14-19 years) and adulthood and senescence (20- 90 years). This breakdown is strongly contested in contemporary studies, since adulthood and senescence encompass a multiplicity of practices and dynamics that would require further distribution, and from a paediatric point of view, childhood must be even more in-depth. The fundamental problem in developmental psychology and motor science studies is that adolescents are the age group most neglected by empirical research (Bernabini, et al., 2020). Although all age groups have peculiar and fundamental characteristics related to the development of cognitive dimensions, according to recent studies in the psychology of adolescent development, it is precisely the pre-adolescent dynamics that most influence the cognitive (and consequently motor) development of the adult subject.

\section{METHODS AND MATERIALS}

The cumulative literature review, a new and rigorous research method, is divided into ten phases (Ghirotto, 2020): 
1 Selection of key concepts (especially of independent and dependent variables and relationships between them).

2 Creation of a search string (in addition to selecting the keywords, it is necessary to include and exclude the studies found through the criteria used). The final goal of this phase of the research is to find a manageable number of studies through the following procedure: 1 ) query two or three search engines or databases; 2) use keywords in combination with 'and/or'; 3) use filters to manage the enormity of the results (comparison with a second researcher as in this study would be desirable).

3 Export of the results from the databases and a merge of all the transcribed results in the form of a bibliography on a single worksheet.

4 Selection of primary sources by eliminating duplicates and excluding irrelevant studies based on title. It is necessary to create a separate list of systematic reviews on the topic. It is also necessary to draw up a list of the individual choices of the cumulative review.

5 Verification of the secondary bibliography, checking above all the bibliographies of all the studies included. Studies that cite primary sources, such as other systematic reviews on the topic, must therefore be included in the studies not found in the initial search of secondary ones.

6 Data extraction (produced by the reviewers' work), in which the characteristics of the selected studies are extrapolated. These characteristics include key variables, type of research project, context, results, year of publication, etc. The exclusion criteria are also cumulative; i.e., they are formulated on the basis of the time available and the studies retrieved in the databases.

7 Updating of the results with recent publications, which may prompt an update regarding the initial work carried out. This must be done before the conclusion of the cumulative review.

8 Verification by the second reviewer, who checks the included studies.

9 Writing of the last phase of the report.

10 Exercising of care of the publicization of the revision. It is necessary to make the data collection work explicit in the form of the paper: keywords, extracted data, results, etc ().

\section{RESULTS}

In this study, research according to the cumulative literature review model followed the ten-phase model set out in the previous paragraph. Specifically, the following keywords were selected: motor competences; developmental age, motor development, (phase 1). Scopus, WoS and Google Scholar were selected as search engines. The search yielded 1000 results that were selected from the comparison of researchers through the following inclusion-exclusion criteria: inclusion of all literature reviews in the 2014-2020 period, related studies prenatal effects on motor development and studies on the effects of motor development on atypical development (phase 2), with exclusion based on primary source titles. The raw research data was transcribed in a spreadsheet to enable a global view of the studies located and to start the selection work (phase 3). The file was 'cleaned up' to remove duplicate contributions and create a second list of systematic reviews of the literature $(n=5)$ (phase 4). In the first file, called 'primary sources', the significant studies were 
selected based on the title. The cleaned file contained $n=11$ papers. In the second file of the systematic reviews of the literature, the secondary bibliography included was consulted, and the studies already present in the first file of the present research were eliminated. in this case, $70 \%$ of the studies had already been identified in the comparison of the cumulative literature reviews. It would be desirable to build a reliability index of the cumulative review that took into account this value, i.e., the degree of replicability of the systematic studies already conducted) (phase 5). Construction of a grid (table 1) with the results of the research and data extraction by the researchers who analysed the key variables (key variables, type of research project, context, results, year of publication, etc.) by selecting as reported in table only the fields relevant to the research (phase 6). The research of the sources carried out in the first months of 2020 has been updated with more recent publications that have introduced a new trend in the studies of motor and cognitive development (effects of the COVID emergency in terms of physical, cognitive and relational development). On the basis of the inclusion-exclusion criteria, other $\mathrm{n} .=2$ papers were included (phase 7). The complete file, with the studies considered significant for the purposes of the construction of this work, was analysed by the second researcher in order to avoid errors in the research (phase 8). Steps 9 and 10 resulted in the production of this research paper.

\section{DISCUSSION}

It is clear from the selected articles that the idea present in the introduction is confirmed: the greatest number of studies on the motor components that have an effect on the development of the subject relate to the 0-5 age group. A good number of studies concern the school period (6-12), while there are no studies on adolescents and adults that address the relevant topic. In fact, in the course of the research it emerged that the studies on adulthood and senescence still focus on rehabilitation and its effects in terms of health. They were therefore excluded from this study.

Table 1 Results of cumulative review.

\begin{tabular}{|l|l|l|l|l|l|}
\hline Paper & Type & $\begin{array}{l}\text { Number of } \\
\text { participants or } \\
\text { studies }\end{array}$ & Themes & Year & $\begin{array}{l}\text { Age of } \\
\text { population }\end{array}$ \\
\hline $\begin{array}{l}\text { Tepe, et al. } \\
\text { (2020). }\end{array}$ & Paper & $93(\mathrm{~F}=42 \mathrm{M}=51)$ & $\begin{array}{l}\text { Motor Skills, Child, Motor } \\
\text { Performance, Motor } \\
\text { Development, Muscle } \\
\text { Development }\end{array}$ & 2020 & $9-10$ \\
\hline $\begin{array}{l}\text { Çalıskan, \& } \\
\text { Süel, (2020). }\end{array}$ & Paper & $120(\mathrm{~F}=60 \mathrm{M}=60)$ & $\begin{array}{l}\text { Motor Development, } \\
\text { Motor Test, TMGD II, } \\
\text { Psychomotor }\end{array}$ & 2020 & $8-9$ \\
\hline $\begin{array}{l}\text { Spinosa, et al. } \\
\text { (2020). }\end{array}$ & Paper & 131 & $\begin{array}{l}\text { human development, } \\
\text { augmented reality, motor } \\
\text { skill }\end{array}$ & 2020 & $3-5$ \\
\hline $\begin{array}{l}\text { Panzilion, et al., } \\
\text { (2020) }\end{array}$ & Paper & 15 & $\begin{array}{l}\text { Brain gym, Puzzle, Motor, } \\
\text { Preschool }\end{array}$ & 2020 & $9-11$ \\
\hline $\begin{array}{l}\text { Heineman, et al., } \\
\text { (2018) }\end{array}$ & Paper & $233 \mathrm{~F}=104$ & $\begin{array}{l}\text { Motor development in } \\
\text { infancy is directly related } \\
\text { to cognitive function at 4 } \\
\text { years of age. } \\
\text { This relationship is most } \\
\text { pronounced for infant } \\
\text { motor variation and } \\
\text { performance. }\end{array}$ & 2018 & 4 \\
\hline
\end{tabular}




\begin{tabular}{|c|c|c|c|c|c|}
\hline & & & $\begin{array}{l}\text { The size of the } \\
\text { differences in } I Q \text { is } \\
\text { clinically relevant. }\end{array}$ & & \\
\hline $\begin{array}{l}\text { Adolph, \& } \\
\text { Franchak, } \\
\text { (2017). }\end{array}$ & Paper & 184 studies & $\begin{array}{l}\text { Development and Aging; } \\
\text { Psychology; Motor Skill } \\
\text { and Performance }\end{array}$ & 2017 & $0-2$ \\
\hline Lin, et al., (2017) & Paper & 40 & $\begin{array}{l}\text { Touch-screen tablet fine } \\
\text { motor preschool child } \\
\text { development }\end{array}$ & 2017 & $4-6$ \\
\hline $\begin{array}{l}\text { Dordića, et al., } \\
\text { (2016) }\end{array}$ & Paper & 72 & $\begin{array}{l}\text { Preschool children; } \\
\text { Development; Physical } \\
\text { growth; Motor } \\
\text { development; Intelligence }\end{array}$ & 2016 & $5-6$ \\
\hline $\begin{array}{l}\text { Nazario, et al., } \\
(2014)\end{array}$ & Paper & 87 & $\begin{array}{l}\text { Child; Motor development; } \\
\text { Motor skills. }\end{array}$ & 2014 & $8-10$ \\
\hline $\begin{array}{l}\text { Vlahov, et al., } \\
\text { (2014) }\end{array}$ & Paper & $\begin{array}{l}282(M=139 \\
F=143) \\
140(M=75 \quad F=65)\end{array}$ & $\begin{array}{l}\text { Obesity; Motor } \\
\text { Development; physical } \\
\text { fitness than locomotor } \\
\text { skills. }\end{array}$ & 2014 & $\begin{array}{l}44-6 \\
14-16\end{array}$ \\
\hline $\begin{array}{l}\text { Wang, et al., } \\
(2014)\end{array}$ & Paper & 62994 & $\begin{array}{l}\text { Communicative and motor } \\
\text { development, motor skill }\end{array}$ & 2014 & $0-3$ \\
\hline $\begin{array}{l}\text { Aguilar-Farias, et } \\
\text { al., (2021) }\end{array}$ & Paper & 3157 & $\begin{array}{l}\text { physical activity; } \\
\text { sedentary behaviour; } \\
\text { sleep; active play; outdoor } \\
\text { time; movement } \\
\text { behaviours; COVID-19 }\end{array}$ & 2021 & $1-5$ \\
\hline Sá, et al., (2021) & paper & 816 & $\begin{array}{l}\text { Quarantine; Screen time; } \\
\text { Sedentary behaviour; } \\
\text { Motor activity; Child } \\
\text { development }\end{array}$ & 2021 & $0-12$ \\
\hline $\begin{array}{l}\text { French, et al., } \\
(2020)\end{array}$ & review & 51 papers & $\begin{array}{l}\text { child health cognitive } \\
\text { development early child } \\
\text { development growth }\end{array}$ & 2020 & $0-8$ \\
\hline $\begin{array}{l}\text { Best, et al., } \\
(2010)\end{array}$ & review & 10 papers & $\begin{array}{l}\text { Aerobic exercise Physical } \\
\text { activity Executive function } \\
\text { Cognition } \\
\text { Infancy/childhood }\end{array}$ & 2010 & $2-16$ \\
\hline $\begin{array}{l}\text { Sterdt, et al., } \\
\text { (2014) }\end{array}$ & review & 48 papers & $\begin{array}{l}\text { adolescents, children, } \\
\text { correlates, physical } \\
\text { activity, }\end{array}$ & 2009 & $3-18$ \\
\hline $\begin{array}{l}\text { Strooband, et al., } \\
(2020)\end{array}$ & review & 31 papers & $\begin{array}{l}\text { Motor Skill } \\
\text { Interventions to Improve } \\
\text { Fine Motor Development } \\
\text { in Children }\end{array}$ & 2020 & $0-6$ \\
\hline $\begin{array}{l}\text { Leonard, et al., } \\
\text { (2014) }\end{array}$ & review & 18 papers & $\begin{array}{l}\text { Motor development social } \\
\text { cognition developmental } \\
\text { coordination language } \\
\text { impairment }\end{array}$ & 2014 & $0-6$ \\
\hline
\end{tabular}

Adolescence, on the other hand, is still a poorly studied period in relation to the cognitive, social and perceptual correlates associated with motor development. Among the articles presented, the mostinvestigated topics were the relationships between motor development and nutrition, anthropometry, play in 
all its dimensions (competitive, symbolic and emotional), spatial perception and IQ. An interesting line of research that has recently developed, as is clear from the results that emerged, concerns the positive/negative effects of technologies on motor development, in particular if they can support or hinder movement. Finally, the studies published the last year of research considered focused on the effects that social distancing and isolation during the Covid-19 pandemic have had on physical activity in the present, and how these have had secondary effects on relationships, emotions and sociability. Neurodevelopment studies have shown that from the visual cortex the dorsal-dorsal pathway is involved in the organization of motor activities, while the dorsal-ventral pathway has a fundamental role in cognitive processes related to action. The two processes are the basis of exploratory strategies and motor proving (Rizzolatti \& Luppino, 2015).

\section{CONCLUSIONS}

Although the subject has been included in the exclusion criteria, there is an important line of studies $(n=243)$ of the effects of motor development in the atypical and pathological development of the child (for which further investigation in the research perspectives would be necessary). From an evolutionary perspective, the motor act is the set of movements oriented to a purpose, while the action is a sequence of motor acts oriented to a purpose. If it is true that the purpose guides the chain of movements, it is also true that to achieve it, mental structures are needed to organize the motor system (Berns et al., 2020). Brain maturation, together with physiological and musculoskeletal development, determine the evolution of motor development. In the same way, motor development and cerebral maturation do not end either with birth or with adulthood. In other words, motor development is determined by brain modulation, which is in turn influenced by the individual's living environment (Piña Díaz, et al.,2020). For instance, sport as an experience is an environmental factor capable of making changes to neuronal functions, affecting the structure and function of the brain, which is plastic.

Even given the extreme individual variability in the stages of development, it is possible to identify a fairly stable temporal succession of motor development. From the first years of life, it is not precocity that is important (although that is important in the construction of the child's motor skills), but the mastery of movement, experimentation and the ability to move independently. From the studies consulted in this review, it is possible to conclude that physical exercise affects the brain and improves the function of neuronal connections. In fact, the brain, even in an adult subject, maintains a certain condition of well-being through sport, because it is necessary to involve multiple cognitive systems, such as motivational, rational and personality systems (Behzadnia, et al. 2019; Toto \& Limone, 2019). Finally, physical activity induces wellbeing both from a psychological point of view, because it increases self-efficacy and self-esteem, and prevents potentially pathological behaviours. In fact, physical activity is a development area for the treatment of pathological addictions such as technology addiction. In addition, physical activity improves social relationships, and enhances the functioning and activation of the neuronal systems that are the basis of all human behaviours.

\section{REFERENCES}

Adolph, K. E., \& Franchak, J. M. (2017). The development of motor behavior. Wiley Interdisciplinary Reviews: Cognitive Science, 8(1-2), e1430. https://doi.org/10.1002/wcs.1430

Aguilar-Farias, N., Toledo-Vargas, M., Miranda-Marquez, S., Cortinez-O'Ryan, A., Cristi-Montero, C., Rodriguez-Rodriguez, F., ... \& del Pozo Cruz, B. (2021). Sociodemographic Predictors of Changes in Physical Activity, Screen Time, and Sleep among Toddlers and Preschoolers in Chile during the 
COVID-19 Pandemic. International journal of environmental research and public health, 18(1), 176. https://doi.org/10.3390/ijerph18010176

Barahona, J. D., García, J. M., \& Pañego, M. M. (2019). Estudio de las actitudes y el interés de los docentes de primaria de educación física por las TIC en la Comunidad Valenciana. Retos: nuevas tendencias en educación física, deporte y recreación, (35), 267-272. https://doi.org/10.47197/retos.v0i35.63355

Behzadnia, B., Mohammadzadeh, H. \& Ahmadi, M. (2019). Autonomy-supportive behaviors promote autonomous motivation, knowledge structures, motor skills learning and performance in physical education. Curr Psychol 38, 1692-1705. https://doi.org/10.1007/s12144-017-9727-0

Bernabini, L., Tobia, V., Guarini, A., \& Bonifacci, P. (2020). Predictors of Children's Early Numeracy: Environmental Variables, Intergenerational Pathways, and Children's Cognitive, Linguistic, and Nonsymbolic Number Skills. Frontiers in Psychology, 11. https://doi.org/10.3389/fpsyg.2020.505065

Berns, C., Brüchle, W., Scho, S. et al. (2020). Intensity dependent effect of cognitive training on motor cortical plasticity and cognitive performance in humans. Exp Brain Res 238, 2805-2818. https://doi.org/10.1007/s00221-020-05933-5

Çalışkan, O., \& Süel, E. (2020). Investigation of the psychomotor development levels of girls and boys in the 8 and 9 age groups according to the TGMD-II Test. Journal of Human Sciences, 17(4), 12851296. https://doi.org/10.14687/ihs.v17i4.6104

Di Pellegrino, G., Fadiga, L., Fogassi, L., Gallese, V., \& Rizzolatti, G. (1992). Understanding motor events: a neurophysiological study. Experimental brain research, 91(1), 176-180. https://doi.org/10.1007/BF00230027

Dordića, V., Tubića, T., \& JaNśića, D. (2016). The relationship between physical, motor, and intellectual development of preschool children. Procedia-Social and Behavioral Sciences, 233, 3-7. https://doi.org/10.1016/j.sbspro.2016.10.114

Ghirotto L., (2020). La systematic review nella ricerca qualitativa. Metodi e strategie. Roma, Carocci.

Heineman, K. R., Schendelaar, P., Van den Heuvel, E. R., \& Hadders-Algra, M. (2018). Motor development in infancy is related to cognitive function at 4 years of age. Developmental Medicine \& Child Neurology, 60(11), 1149-1155. https://doi.org/10.1111/dmcn.13761

Limone, P., \& Toto, G. A. (2018). The psychological constructs and dimensions applied to sports performance: a change of theoretical paradigms. Journal of Physical Education and Sport, 18, 20342038.

Lin, L. Y., Cherng, R. J., \& Chen, Y. J. (2017). Effect of touch screen tablet use on fine motor development of young children. Physical \& occupational therapy in pediatrics, 37(5), 457-467. https://doi.org/10.1080/01942638.2016.1255290

Nazario, P. F., \& Vieira, J. L. L. (2014). Sport context and the motor development of children. Revista Brasileira de Cineantropometria \& Desempenho Humano, 16(1), 86-95. https://doi.org/10.5007/1980-0037.2014v16n1p86

Panzilion, P., Padila, P., Setyawati, A. D., Harsismanto, J., \& Sartika, A. (2020). Stimulation of Preschool Motor Development Through Brain Gym and Puzzle. JOSING: Journal of Nursing and Health, 1(1), 10-17.

Piña Díaz, D., Ochoa-Martínez, P., Hall-López, J., Reyes Castro, Z., Alarcón Meza, E., Monreal Ortiz, L., \& Sáenz-López Buñuel, P. (2020). Efecto de un programa de educación física con intensidad moderada vigorosa sobre el desarrollo motor en niños de preescolar (Effect of a physical education program with moderate-to-vigorous intensity on motor development in preschool children). Retos, 38(38), 363-368. https://doi.org/10.47197/retos.v38i38.73818 
Rizzolatti, G., \& Luppino, G. (2015). Premotor Cortex. In International Encyclopedia of the Social \& Behavioral Sciences: Second Edition. (pp.846-851) Elvesier. https://doi.org/10.1016/B978-0-08097086-8.55046-6

Rollo, D., Longobardi, E., Spataro, P., \& Sulla, F. (2017). The construction of self in relationships: Narratives and references to mental states during picture-book reading interactions between mothers and children. Frontiers in Psychology, 8, 2060. https://doi.org/10.3389/fpsyg.2017.02060

Sá, C. D. S. C. D., Pombo, A., Luz, C., Rodrigues, L. P., \& Cordovil, R. (2021). Covid-19 social isolation in brazil: effects on the physical activity routine of families with children. Revista Paulista de Pediatria, 39. 0-12. https://doi.org/10.1590/1984-0462/2021/39/2020159

Spinosa, R. M. D. O., Santo, D. L. D., Costa, R. Z. F., Pazetto, N. F., Santos, C. R. D., Medina-Papst, J., \& Marques, I. (2020). Comparing Live and Digital Augmented Reality Models for Demonstrating Two Motor Skills From the Test of Gross Motor Development-Second Edition: TGMD-2. Perceptual and Motor Skills, 127(2), 386-400. https://doi.org/10.1177/0031512519900061

Tepe, M. G., Şahin, I., \& Kalebozan, T. (2020). Determination of The Motor Development Levels of 9-10 Years Old Children. Türk Spor ve Egzersiz Dergisi, 22(2), 352-359.

Toto, G. A., \& Limone, P. (2019). Self-directed learning: An innovative strategy for sport and physical education. Journal of Human Sport and Exercise. 14(Proc4): S568-S577. https://doi.org/10.14198/ihse.2019.14.Proc4.14

Vlahov, E., Baghurst, T. M., \& Mwavita, M. (2014). Preschool motor development predicting high school health-related physical fitness: a prospective study. Perceptual and motor skills, 119(1), 279-291. https://doi.org/10.2466/10.25.PMS.119c16z8

Wang, M. V., Lekhal, R., Aarø, L. E., \& Schjølberg, S. (2014). Co-occurring development of early childhood communication and motor skills: results from a population-based longitudinal study. Child: care, health and development, 40(1), 77-84. https://doi.org/10.1111/cch.12003

\section{(9) $(\oplus \Theta \Theta$}

This work is licensed under a Attribution-NonCommercial-NoDerivatives 4.0 International (CC BY-NC-ND 4.0). 